\title{
Rootstock Influences on Health and Growth Following Candidatus Liberibacter asiaticus Infection in Young Sweet Orange Trees
}

\author{
Kim D. Bowman ${ }^{1, *}$ and Ute Albrecht ${ }^{2}$ (D) \\ 1 United States Horticultural Research Laboratory, Agricultural Research Service, \\ United States Department of Agriculture, Fort Pierce, FL 34945, USA \\ 2 Southwest Florida Research and Education Center, Horticultural Sciences Department, \\ Institute of Food and Agricultural Sciences, University of Florida, Immokalee, FL 34142, USA; \\ ualbrecht@ufl.edu \\ * Correspondence: kim.bowman@usda.gov
}

Received: 2 October 2020; Accepted: 30 November 2020; Published: 2 December 2020

\begin{abstract}
Health, growth, fruit production, and fruit quality of citrus crops are severely affected by tree infection with Candidatus Liberibacter asiaticus (CLas) and subsequent development of the disease huanglongbing (HLB). The use of HLB-tolerant rootstocks is one strategy that is used to ameliorate the effects of HLB in commercial production. Although there is a clear long-term rootstock effect to improve tree performance, such field trials take many years for establishment and evaluation, and this long time-period is very limiting to expeditious evaluation of new rootstocks. In this study, we have conducted a 50-week greenhouse experiment to evaluate rootstock influences on Valencia sweet orange tree response to CLas infection. The infection of trees with CLas reduced scion and rootstock growth, increased leaf yellowing, and reduced the number of leaves per tree and leaf area, regardless of rootstock. There were clear rootstock influences on some traits during the 50-week study. In general, infected trees on US-942 rootstock had lower CLas root titers, less reduction of the number of leaves, less reduction of leaf area, and less leaf yellowing, as compared with some of the other rootstocks. The 50-week greenhouse evaluation method provided results that corresponded well with results from long-term field testing, indicating this may be a useful tool to accelerate evaluation and selection of new rootstocks, as well as in testing other HLB management strategies.
\end{abstract}

Keywords: citrus greening; huanglongbing; rootstock; Swingle; sour orange; US-802; US-812; US-897; US-942; US-1516

\section{Introduction}

Production of citrus crops in many regions of the world is threatened or already severely affected by huanglongbing disease (HLB), associated with the phloem-limited bacteria Candidatus Liberibacter asiaticus (CLas). Infected citrus trees suffer from reduced vigor, shoot dieback, a thinning of the leaf canopy, leaf blotchy mottle and chlorosis, reduced fruit crop, and reduced fruit quality. In Florida, sweet orange production has declined by about 70\% since HLB was first discovered in 2005, from about 9.2 billion $\mathrm{kg}$ per season from 2001-2004, down to 2.7 billion $\mathrm{kg}$ for the season ending in 2020 [1,2]. Through research and practical experience, Florida growers have identified several strategies as being most useful to reduce the impact of HLB in citrus groves, including suppression of the disease vector Asian Citrus Psyllid [3,4], improved nutritional management [5,6], use of HLB-tolerant scions [7,8], and rootstocks [9].

Citrus rootstocks have been used for many years as a tool to increase fruit production and fruit quality, regulate tree size, and improve tolerance to disease or pests [10-12]. Several sources of 
tolerance to CLas have been reported within the citrus gene pool, including Poncirus trifoliata [13,14]. Hybrids among P. trifoliata and Citrus are common among commercially important citrus rootstocks, and some of these hybrids have been described to have superior field performance in field trials severely affected by HLB $[15,16]$. Two commercially important hybrids of $C$. reticulata $\times$ P. trifoliata, US-897 and US-942, have been studied in some detail for seedling response to infection by CLas, including influence on symptoms and growth, gene expression, and metabolomics [13,17-19]. Recently, we have described the metabolomics response at 28 weeks after infection of sweet orange grafted on several rootstocks, including Citrus spp. $\times$ P. trifoliata hybrids, to CLas infection under controlled conditions [20]. In this current study, we report the significant influence of eleven rootstocks (including 8 hybrids of $P$. trifoliata) on the growth, health, and CLas leaf and root titer in grafted sweet orange trees through the first 50 weeks following infection. The results from this greenhouse test were found to correspond well with long-term field evaluations under endemic CLas conditions.

\section{Materials and Methods}

\subsection{Rootstock Material}

Eleven citrus rootstocks were used in the study (Table 1), five rootstocks of long-term commercial importance (including two that were released by USDA more than 40 years ago), five popular USDA hybrid rootstocks released in the last 20 years, and one other USDA hybrid rootstock being considered for commercial release [12,16]. All eleven rootstocks are efficiently propagated by uniform nucellar seedlings [21], and for this study were grown from certified seed source trees located at the Whitmore Foundation Farm (Groveland, FL, USA) for the respective rootstocks. The seed were harvested from the source trees in the previous season, treated with 8-hydroxyquinoline sulfate, and stored at $4{ }^{\circ} \mathrm{C}$ until use.

Table 1. Citrus rootstock cultivars used in the study, with parentage and release date.

\begin{tabular}{llc}
\hline Rootstock & Parentage & USDA Release Date \\
\hline Carrizo & Citrus sinensis $\times$ Poncirus trifoliata & 1934 \\
Cleopatra & Citrus reticulata & NA \\
Ridge orange & Citrus sinensis & NA \\
Sour orange & Citrus aurantium & NA \\
Swingle & Citrus paradisi $\times$ Poncirus trifoliata & 1974 \\
US-802 & Citrus maxima “Siamese" $\times$ P. trifoliata “Gotha Road" & 2007 \\
US-812 & Citrus reticulata "Sunki": $\times$ P. trifoliata "Benecke" \\
US-896 a & C. reticulata "Cleopatra" $\times$ P. trifoliata "Rubidoux" & 2001 \\
US-897 & C. reticulata "Cleopatra" $\times$ P. trifoliata "Flying Dragon" & NA \\
US-942 & C. reticulata "Sunki" $\times$ P. trifoliata "Flying Dragon" & 2007 \\
US-1516 & C. maxima "African" $\times$ P. trifoliata "Flying Dragon" & 2010 \\
\hline & \multicolumn{2}{c}{ a US-896 rootstock is a USDA hybrid, but has not yet been released. }
\end{tabular}

\subsection{Rootstock Preparation}

Rootstock seed were planted in soilless potting mix (Pro Mix BX; Premier Horticulture, Inc., Quakertown, PA, USA), using racks of $3.8 \mathrm{~cm} \times 21 \mathrm{~cm}$ cone cells (Cone-tainers; Stuewe and Sons, Tangent, OR, USA) and grown in a temperature-controlled greenhouse, as described below, to $>40 \mathrm{~cm}$ height. Selected true-to-type plants of each rootstock were transplanted into $2.54 \mathrm{~L}$ pots (Treepots; Stuewe and Sons) using the soilless potting mix (Pro Mix BX) 8 weeks before scion grafting.

\subsection{Growing Conditions}

During preparation of the trees and throughout the experiments, rootstock liners and grafted trees were grown without supplemental light and in a temperature-controlled greenhouse at the US Horticultural Research Laboratory in Ft. Pierce, Florida. During the experimentation, the greenhouse 
had a mean weekly temperature of $26.5^{\circ} \mathrm{C}$ to $29.7^{\circ} \mathrm{C}$. Plants received a liquid fertilizer application of water-soluble fertilizer (20N-10P-20K; Peters Professional, The Scotts Company, Marysville, OH, USA) every other week, at a rate of $400 \mathrm{mg} \mathrm{N}$ per liter. Between fertilizer applications, plants were irrigated with water as needed. Insecticides and miticides were applied as needed.

\subsection{Grafting the Scion}

At a suitable size (about 5-6 months after seeding), liners of the rootstocks were budded with the certified sweet orange (C. sinensis) scion clone Valencia 1-14-19, obtained from Florida Department of Agriculture and Consumer Services-DPI (FDACS-DPI, Winter Haven, FL, USA). Grafting of the Valencia scion onto the rootstock liner was by inverted $\mathrm{T}$ bud, and grafted buds were wrapped with budding tape for 2 weeks. One week after unwrapping the buds, the rootstock was trimmed and looped to force bud growth, using methods as previously described [22].

\subsection{Inoculation with CLas}

After trees of Valencia scion on the different rootstocks reached suitable size, stem diameter of the scion was measured, and trees were divided by rootstock into two groups with equal mean stem size to mock-inoculate and graft inoculate with CLas using the inverted T bud method as described previously [8]. For trees on each rootstock, one group (22-35 trees per rootstock; except US-1516, which contained 12 trees) was inoculated with CLas-infected budwood from Cleopatra seedlings both symptomatic and PCR-positive for CLas $\left(\mathrm{Ct}_{\mathrm{CLas}}<25\right)$. A second group (13-14 trees per rootstock; except US-1516, which contained 8 trees) to be used as a control was mock-inoculated with CLas-free budwood from Cleopatra seedlings not symptomatic and PCR-negative for CLas (Ct $\mathrm{CLas}_{\mathrm{s}}$ not detected). Each tree was inoculated with three buds, with one bud from each of three different Cleopatra seedlings. Trees were pruned immediately after inoculation to stimulate CLas spread through the tree. Two weeks after bud-inoculation, bud wraps were removed. Only trees with at least two surviving buds were used for the continuation of the experiment.

\subsection{Transplanting to Larger Pots}

Six CLas-inoculated trees that became CLas-positive by leaf and/or root detection (see Section 2.7) were selected from each rootstock, except Swingle, US-1516, US-802, US-896, and US-897, for which only 4 or 5 CLas-positive plants were recovered. This resulted in a total of 57 CLas-positive trees used for the study; an equal number of mock-inoculated and CLas-negative trees for each rootstock was included. These trees were transplanted to larger $5.0 \mathrm{~L}$ pots (Treepots; Stuewe and Sons) at 30 weeks after inoculation (wai) to allow for continuing tree growth, using the soilless potting mix (Pro Mix BX). Trees were pruned following transplanting to encourage new growth that could be used for leaf sample collection and symptom scoring.

\subsection{PCR Detection of CLas in Leaves and Roots}

For the detection of CLas in the canopy, four to six fully expanded leaves were collected from each plant at 10, 20, 28, 40, and 50 wai, or August, October, December, February, and May, respectively. Leaf samples were stored at $-20^{\circ} \mathrm{C}$ for DNA extraction. Petioles and parts of the midrib were severed from the rest of the leaf blade and ground in liquid nitrogen with a mortar and pestle. One hundred milligrams of ground tissue was used for DNA extraction. DNA was extracted using the Plant DNeasy ${ }^{\circledR}$ Mini Kit (Qiagen, Valencia, CA, USA) according to the manufacturer's instructions. The yield and purity of DNA was determined by measuring OD260 nm and OD260 nm/280 nm, respectively using a Nanodrop spectrophotometer. For detection of CLas, primers for HLBas, HLBr, and probe HLBp, developed by Li et al. [23], were used to perform real-time PCR assays in an AB7500 real-time PCR system (Applied Biosystems, Foster City, CA, USA) and using the QuantiTect Probe PCR Kit (Qiagen). All reactions were carried out in a $20-\mu \mathrm{L}$ reaction volume using $100 \mathrm{ng}$ DNA. For normalization and DNA quality control, all samples were also assayed using primers COXf and COXr, and probe 
COXp [23]. The amplification cycling conditions were Taq activation at $95^{\circ} \mathrm{C}$ for $15 \mathrm{~min}$ followed by 40 cycles of denaturing at $94{ }^{\circ} \mathrm{C}$ for $15 \mathrm{~s}$ and annealing at $60^{\circ} \mathrm{C}$ for $60 \mathrm{~s}$. Plants selected to represent CLas-infected plants for evaluation beyond 20 wai had normalized $\mathrm{Ct}_{\text {CLAS }}$ values for leaves and/or roots that were $\leq 38$ during the course of the study, and were determined to be CLas-positive.

For detection of CLas in the root system, fibrous roots were collected from each plant at 10, 20, 28, 40 , and 50 wai. Fibrous roots were collected from an area at least 2 inches from the bottom of the pot and 2 inches from the soil surface. Root samples were washed under running tap water, blotted dry and stored at $-20^{\circ} \mathrm{C}$ for DNA extraction. The remaining steps of root sample processing for PCR were identical to that used for leaves, as described above.

\subsection{Data Collection and Analysis}

Scion and rootstock stem diameters were measured at 30 wai and 50 wai. Values were converted to trunk cross sectional area (TCSA) and expressed as percent increase in TCSA from time 30 wai to 50 wai for data analysis.

At 50 wai, all fully expanded leaves on trees were scored for HLB asymmetric blotchy mottle symptoms [24] and leaf color. Each individual leaf was scored for HLB blotchy mottle symptoms on a 1-4 scale, with $1=$ no blotchy mottle, and $4=$ strong blotchy mottle. Each individual leaf was scored for leaf color on a $1-4$ scale, with $1=$ normal green color, and $4=$ yellow. All fully expanded leaves were counted, and leaf areas measured using a LI-3100C leaf area meter (LI-COR Biosciences, Lincoln, NE, USA).

Data were analyzed using Statistica software (Version 10; Tibco Software Inc., Palo Alto, CA, USA). Comparison of rootstock effects for each trait was by one-way ANOVA. Mean separation for significant $(p<0.05)$ ANOVA results was by Tukey's HSD test at $\alpha=0.05$.

\section{Results}

\subsection{PCR Detection of CLas}

Of the 57 CLas-positive trees used for the study, 24 trees (42\%) were CLas-positive in the leaves $\left(\right.$ Ct $\left._{\text {CLAS }} \leq 38\right)$, and 27 trees $(47 \%)$ were CLas-positive in the roots at 10 wai. This changed to 54 trees (95\%) CLas-positive in the leaves, and 36 trees (36\%) CLas-positive in the roots at 20 wai.

Overall values for leaf-Ct $t_{\text {CLAS }}$ declined over the time-course of the study from 36.2 to 25.8 (Table 2). This equates to an increasing CLas population from an average 380 CLas genome copies per $\mathrm{g}$ leaf tissue at 10 wai, to an average 809,000 CLas genome copies per g leaf tissue at 50 wai, based on the formula described by Albrecht and Bowman [14]. Mean leaf-Ct ${ }_{C L A S}$ values differed among the rootstocks at each time point, but variability was high and there was no significant difference among rootstocks in their influence on $\mathrm{Ct}_{\text {CLAS }}$ of the scion leaf.

Mean root-Ct $t_{\text {CLAS }}$ remained relatively high throughout the time-course of the study (Table 3). The difference between leaf and root-Ct $t_{\text {CLAS }}$ was especially pronounced at 50 wai, when mean root-Ct $t_{\text {CLAS }}$ was 34.0, or about 1900 CLas genome copies per g root tissue. This was a mean CLas population in root tissue more than $400 \times$ lower than the CLas population in leaf tissue at the same age. In addition, there were significant differences between root-C $\mathrm{t}_{\mathrm{CLAS}}$ values of different rootstocks at all times, with Ridge and sour orange mean root-Ct $\mathrm{CLAS}_{\text {LAS }}$ values less than 31.2 throughout 20-50 wai,

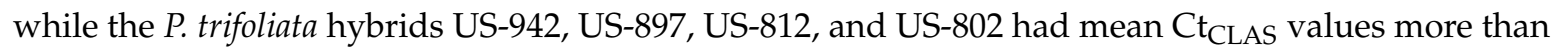
34.5 at all time points. 
Table 2. Leaf Ct-values of infected plants used for assessment of horticultural parameters.

\begin{tabular}{lccccc}
\hline Rootstock & 10 wai & 20 wai & 28 wai & 40 wai & 50 wai \\
\hline Sour orange & 35.2 & 27.2 & 27.2 & 23.6 & 24.6 \\
Ridge & 36.4 & 30.0 & 30.7 & 26.0 & 25.8 \\
US-1516 & 37.3 & 32.4 & 33.7 & 25.3 & 26.4 \\
Swingle & 32.6 & 25.2 & 25.8 & 22.9 & 25.3 \\
Carrizo & 35.9 & 32.7 & 29.9 & 25.0 & 26.5 \\
Cleopatra & 31.9 & 28.5 & 29.5 & 24.4 & 24.5 \\
US-896 & 33.7 & 30.2 & 30.2 & 25.4 & 26.0 \\
US-802 & 38.3 & 31.5 & 33.7 & 29.3 & 29.3 \\
US-812 & 39.9 & 26.3 & 27.8 & 26.0 & 26.6 \\
US-897 & 41.0 & 28.3 & 30.1 & 24.7 & 24.0 \\
US-942 & 37.5 & 32.1 & 28.4 & 26.3 & 25.9 \\
Average & 36.2 & 29.5 & 29.5 & 25.3 & 25.8 \\
-value & 0.3843 & 0.2508 & 0.3251 & 0.1605 & 0.2483 \\
\hline
\end{tabular}

Cell shading reflects $\mathrm{Ct}$-value category, with darker blue indicating higher $\mathrm{Ct}$-values and darker red indicating lower Ct-values. No amplification products were detected for control plants (mean $\mathrm{Ct}>40$ ).

Table 3. Root Ct-values of infected plants used for assessment of horticultural parameters.

\begin{tabular}{|c|c|c|c|c|c|c|c|c|c|c|}
\hline \multirow{2}{*}{$\begin{array}{l}\text { Rootstock } \\
\text { Sour } \\
\text { orange }\end{array}$} & \multicolumn{2}{|c|}{10 wai } & \multicolumn{2}{|c|}{20 wai } & \multicolumn{2}{|c|}{28 wai } & \multicolumn{2}{|c|}{40 wai } & \multicolumn{2}{|c|}{50 wai } \\
\hline & 35.4 & $a b$ & 30.6 & $\mathrm{~b}$ & 28.5 & d & 27.8 & a & 30.7 & $b$ \\
\hline Ridge & 32.8 & $\mathrm{~b}$ & 31.2 & $a b$ & 28.9 & d & 29.1 & a & 31.0 & $b$ \\
\hline US-1516 & 37.0 & $a b$ & 36.5 & $a b$ & 33.7 & $a-d$ & 31.5 & a & 31.8 & $a b$ \\
\hline Swingle & 34.7 & $a b$ & 29.8 & $\mathrm{~b}$ & 32.0 & $b-d$ & 29.4 & a & 32.4 & $a b$ \\
\hline Carrizo & 39.5 & $a b$ & 34.7 & $a b$ & 31.4 & $\mathrm{~cd}$ & 33.5 & a & 32.4 & $a b$ \\
\hline Cleopatra & 32.6 & $\mathrm{~b}$ & 35.1 & $a b$ & 32.8 & $b-d$ & 32.0 & a & 34.3 & $\mathrm{ab}$ \\
\hline US-896 & 39.7 & $a b$ & 34.4 & $a b$ & 36.5 & $a-c$ & 34.7 & a & 34.8 & $a b$ \\
\hline US-802 & 39.9 & $a b$ & 39.2 & $a b$ & 40.2 & a & 35.3 & $\mathrm{a}$ & 35.2 & $a b$ \\
\hline US-812 & 36.4 & $a b$ & 36.2 & $a b$ & 36.2 & $a-c$ & 34.7 & a & 36.2 & $a b$ \\
\hline US-897 & 41.0 & $\mathrm{a}$ & 40.5 & $\mathrm{a}$ & 39.4 & $a b$ & 36.4 & a & 36.9 & $\mathrm{ab}$ \\
\hline US-942 & 39.5 & $a b$ & 38.3 & $a b$ & 37.1 & $a-c$ & 34.5 & a & 38.5 & a \\
\hline Average & 36.9 & & 34.9 & & 33.9 & & 32.5 & & 34 & \\
\hline$p$-value & 0.002 & & 0.003 & & $<0.0001$ & & 0.019 & & 0.015 & \\
\hline
\end{tabular}

Different letters within columns indicate significant differences according to Tukey's HSD test. Cell shading reflects $\mathrm{Ct}$-value category, with darker blue indicating higher $\mathrm{Ct}$-values and darker red indicating lower $\mathrm{Ct}$-values.

\subsection{Tree Growth and Size Measured by TCSA in Scion and Rootstock}

There was a significant influence of rootstock on scion growth of mock-inoculated CLas-negative trees, both as measured by scion TCSA at 50 wai, and increase in scion TCSA from 30 to 50 wai (Table 4). For both measures, Ridge produced the largest and fastest growing trees, while Swingle, US-812 and US-1516 produced the smallest and slowest growing trees.

Although only significant at a level of $8.5 \%$, there was a trend for rootstock to influence scion TCSA at 50 wai for CLas-positive trees, with US-942 providing the largest scion and US-1516 the smallest. There was no evidence that rootstock influenced the relative growth of scion TCSA for CLas-inoculated and CLas-positive trees from 30 to 50 wai, or the ratio of growth for CLas-positive/CLas-negative trees during that time period. Average growth (across all rootstocks) of the scion TCSA from 30 to 50 wai for CLas-infected trees was only about $36 \%$ of the growth of healthy trees.

Rootstock had a significant effect on rootstock TCSA at 50 wai for both CLas-negative and CLas-positive trees (Table 5). For CLas-negative trees, US-802, Swingle, US-897, US-942, and Ridge had the largest rootstock TCSA, while sour orange produced the smallest TCSA. With CLas-positive trees, Carrizo had the largest TCSA, while Cleopatra and sour orange produced the smallest. There was no significant rootstock influence on the relative growth of rootstock TCSA from 30 to 50 wai, regardless of whether trees were infected with CLas or not, and no significant difference for the ratio of CLas-negative 
to CLas-positive trees. The average growth (across all rootstocks) of the rootstock TCSA from 30 to 50 wai for CLas-positive trees was only about $27 \%$ of the growth for healthy trees.

Table 4. Scion size and growth, as trunk cross-sectional area (TCSA) in $\mathrm{mm}^{2}$.

\begin{tabular}{|c|c|c|c|c|c|c|c|}
\hline \multirow{2}{*}{$\begin{array}{l}\text { Rootstock } \\
\text { Ridge }\end{array}$} & \multicolumn{2}{|c|}{$\begin{array}{l}\text { Scion Tcsa } 50 \\
\text { wai Clas neg }\end{array}$} & \multirow{2}{*}{$\begin{array}{c}\begin{array}{c}\text { Scion TCSA } \\
50 \text { wai } \\
\text { Clas pos }\end{array} \\
73\end{array}$} & \multicolumn{2}{|c|}{$\begin{array}{c}\text { Scion TCSA } \Delta \\
30-50 \text { wai }^{\text {a }} \\
\text { Clas neg }\end{array}$} & \multirow{2}{*}{$\begin{array}{c}\text { Scion TCSA } \Delta \\
\begin{array}{c}\text { 30-50 wai } \\
\text { Clas pos }\end{array} \\
16\end{array}$} & \multirow{2}{*}{$\begin{array}{c}\text { Scion TCSA } \\
\begin{array}{c}\Delta 30-50 \text { wai } \\
\text { pos/neg }(\%)\end{array} \\
33\end{array}$} \\
\hline & 133 & $\mathrm{a}$ & & 48 & a & & \\
\hline US-942 & 126 & $\mathrm{ab}$ & 86 & 42 & $\mathrm{ab}$ & 15 & 35 \\
\hline Cleopatra & 125 & $a-c$ & 59 & 43 & $a b$ & 11 & 26 \\
\hline $\begin{array}{l}\text { Sour } \\
\text { orange }\end{array}$ & 110 & $a-d$ & 71 & 38 & $a b$ & 8 & 21 \\
\hline Carrizo & 104 & $b-d$ & 80 & 34 & $\mathrm{ab}$ & 17 & 49 \\
\hline US-897 & 99 & $b-d$ & 62 & 37 & $a b$ & 8 & 24 \\
\hline US-802 & 97 & $b-d$ & 59 & 35 & $a b$ & 16 & 56 \\
\hline US-812 & 96 & $\mathrm{~d}$ & 68 & 26 & $\mathrm{~b}$ & 12 & 47 \\
\hline US-896 & 94 & $\mathrm{~cd}$ & 59 & 27 & $\mathrm{~b}$ & 6 & 26 \\
\hline US-1516 & 89 & $\mathrm{~d}$ & 51 & 36 & $\mathrm{ab}$ & 11 & 32 \\
\hline Swingle & 82 & $\mathrm{~d}$ & 60 & 25 & $\mathrm{~b}$ & 11 & 49 \\
\hline Average & 105 & & 66 & 36 & & 12 & 36 \\
\hline$p$-value & $<0.001$ & & 0.085 & 0.003 & & 0.571 & 0.576 \\
\hline
\end{tabular}

Different letters within columns indicate significant differences according to Tukey's HSD test. ${ }^{\text {a }}$ Scion TCSA $\Delta$ $30-50$ wai indicates the change between scion TCSA at 30 wai and 50 wai.

Table 5. Rootstock size and growth, as trunk cross-sectional area (TCSA) in $\mathrm{mm}^{2}$.

\begin{tabular}{|c|c|c|c|c|c|c|c|}
\hline \multirow{2}{*}{$\begin{array}{l}\text { Rootstock } \\
\text { US-802 }\end{array}$} & \multicolumn{2}{|c|}{$\begin{array}{c}\text { Rootstock } \\
\text { TCSA } \\
50 \text { wai } \\
\text { CLas neg }\end{array}$} & \multicolumn{2}{|c|}{$\begin{array}{c}\text { Rootstock } \\
\text { TCSA } \\
50 \text { wai } \\
\text { CLas pos }\end{array}$} & \multirow{2}{*}{$\begin{array}{c}\text { Rootstock } \\
\text { TCSA } \Delta \\
30-50 \text { wai }{ }^{\text {a }} \\
\text { CLas neg } \\
83\end{array}$} & \multirow{2}{*}{$\begin{array}{c}\text { Rootstock } \\
\text { TCSA } \Delta \\
\text { 30-50 wai } \\
\text { CLas pos } \\
19\end{array}$} & \multirow{2}{*}{$\begin{array}{c}\text { Rootstock } \\
\text { TCSA } \Delta 30-50 \\
\text { wai pos/neg (\%) } \\
27\end{array}$} \\
\hline & 235 & a & 143 & $a b$ & & & \\
\hline Swingle & 225 & a & 143 & $\mathrm{ab}$ & 60 & 16 & 27 \\
\hline US-897 & 224 & $\mathrm{a}$ & 126 & $a b$ & 75 & 6 & 13 \\
\hline US-942 & 215 & $\mathrm{a}$ & 133 & $a b$ & 76 & 20 & 25 \\
\hline Ridge & 206 & a & 114 & $\mathrm{ab}$ & 72 & 20 & 32 \\
\hline Carrizo & 199 & $a b$ & 148 & $\mathrm{a}$ & 66 & 23 & 58 \\
\hline Cleopatra & 193 & $a b$ & 89 & $\mathrm{~b}$ & 64 & 13 & 21 \\
\hline US-812 & 191 & $a b$ & 121 & $a b$ & 64 & 14 & 32 \\
\hline US-1516 & 180 & $a b$ & 111 & $\mathrm{ab}$ & 62 & 11 & 19 \\
\hline US-896 & 179 & $a b$ & 110 & $a b$ & 49 & 8 & 17 \\
\hline $\begin{array}{l}\text { Sour } \\
\text { orange }\end{array}$ & 141 & b & 96 & $\mathrm{~b}$ & 48 & 12 & 29 \\
\hline Average & 199 & & 121 & & 65 & 15 & 27 \\
\hline$p$-value & $<0.001$ & & 0.006 & & 0.410 & 0.734 & 0.797 \\
\hline
\end{tabular}

Different letters within columns indicate significant differences according to Tukey's HSD test. ${ }^{\text {a }}$ Rootstock TCSA $\Delta$ 30-50 wai indicates the change between scion TCSA at 30 wai and 50 wai.

\subsection{Leaf Symptoms of HLB and Leaf Yellowing}

The HLB symptom known as blotchy mottle was only rarely observed in leaves of CLas-positive trees (Table 6), although a generalized yellowing of leaves (that did not present as blotchy mottle) was often observed. Leaf yellowing was influenced by rootstock at a significance level of $5.1 \%$, with a trend for Ridge and Swingle to induce the most yellowing, and US-942 and US-812 the least. 
Table 6. Leaf symptoms of HLB (blotchy mottle) and leaf yellowing at 50 wai.

\begin{tabular}{lccc}
\hline Rootstock & Leaf Blotchy Mottle $^{\mathbf{a}}$ & Leaf Color $^{\mathbf{b}}$ CLas neg & Leaf Color CLas pos \\
\hline Ridge orange & 1.0 & 1.0 & 2.4 \\
Swingle & 1.0 & 1.1 & 2.5 \\
US-1516 & 1.0 & 1.0 & 2.2 \\
Carrizo & 1.0 & 1.0 & 2.2 \\
US-897 & 1.0 & 1.0 & 2.1 \\
US-896 & 1.0 & 1.0 & 2.0 \\
Sour orange & 1.0 & 1.0 & 1.8 \\
US-802 & 1.1 & 1.0 & 1.8 \\
Cleopatra & 1.0 & 1.0 & 1.7 \\
US-812 & 1.0 & 1.0 & 1.6 \\
US-942 & 1.0 & 1.0 & 1.4 \\
Average & 1.0 & 1.0 & 2.0 \\
$p$-value & 0.551 & 0.127 & 0.051 \\
\hline
\end{tabular}

${ }^{a}$ Individual leaf blotchy mottle was scored on a 1-4 scale, with $1=$ no blotchy mottle, and $4=$ strong blotchy mottle;

${ }^{\mathrm{b}}$ Individual leaf color was scored on a $1-4$ scale, with $1=$ normal green color, and $4=$ yellow.

\subsection{Number of Leaves per Tree}

The average number of leaves for CLas-negative trees was 131, and there was no significant rootstock effect at 50 wai (Table 7). The average number of leaves on CLas-infected trees was 49, which was about $37 \%$ of the number of leaves on healthy trees. Rootstock influence on CLas-positive trees was significant only at a level of 7\%, with a trend for CLas-infected trees on US-942 and US-812 rootstocks to have the largest number of leaves per tree (73-81) and infected trees on Cleopatra and Swingle having the smallest number (31-32). The relative effect of CLas infection on the number of leaves per tree, calculated as percentage of leaf number on CLas-infected trees compared to leaf number on healthy trees, showed a significant rootstock influence $(p>F=0.003)$. Trees on US-942 maintained the largest percentage of leaves on infected trees $(71 \%)$, while trees on Cleopatra, Swingle, and Ridge maintained only $20-23 \%$ of their leaves.

Table 7. Number of leaves per tree at 50 wai.

\begin{tabular}{lcccc}
\hline Rootstock & $\begin{array}{c}\text { Leaves per Tree } \\
\text { CLas neg }\end{array}$ & $\begin{array}{c}\text { Leaves per Tree } \\
\text { CLas pos }\end{array}$ & $\begin{array}{c}\text { Leaves per Tree } \\
\text { pos/neg (\%) }\end{array}$ \\
\hline US-942 & 117 & 81 & 71 & $\mathrm{a}$ \\
US-812 & 120 & 73 & 64 & $\mathrm{ab}$ \\
US-802 & 114 & 57 & 48 & $\mathrm{a}-\mathrm{c}$ \\
Sour & 138 & 50 & 39 & $\mathrm{a}-\mathrm{c}$ \\
orange & 147 & 57 & 38 & $\mathrm{a}-\mathrm{c}$ \\
Carrizo & 105 & 36 & 37 & $\mathrm{a}-\mathrm{c}$ \\
US-1516 & 145 & 45 & 33 & $\mathrm{a}-\mathrm{c}$ \\
US-896 & 108 & 36 & 33 & $\mathrm{a}-\mathrm{c}$ \\
US-897 & 150 & 40 & 23 & $\mathrm{bc}$ \\
Ridge & 141 & 32 & 23 & $\mathrm{bc}$ \\
Swingle & 159 & 31 & 20 & $\mathrm{c}$ \\
Cleopatra & 131 & 49 & 39 & \\
Average & 0.138 & 0.070 & 0.003 & \\
p-value & & & & \\
\hline
\end{tabular}

Different letters within columns indicate significant differences according to Tukey's HSD test.

\subsection{Leaf Area per Tree}

Mean total leaf area for healthy trees at 50 wai in the study was $3655 \mathrm{~cm}^{2}$ (Table 8). There was a significant influence of rootstock on the total leaf area for trees not infected by CLas, with trees on Ridge having the largest total leaf area, and trees on US-897 having the smallest total leaf area. 
Mean total leaf area for CLas-positive trees was $956 \mathrm{~cm}^{2}$, or only about $25 \%$ of the leaf area for healthy trees. Values of total leaf area for trees infected by CLas showed large mean differences by rootstock, but had high variability, so no significant effect was measured. The relative effect of CLas infection on the total leaf area per tree, calculated as percent of CLas-infected tree value compared to healthy tree value, showed a significant rootstock influence on this ratio $(p>F=0.036)$. This comparison for total leaf area per tree provided a similar result to that of total leaf number per tree, with trees on the rootstocks US-812 and US-942 maintaining the largest percentage of their total leaf area on infected trees (37-41\%), while CLas-infected trees on Cleopatra, Ridge, and Swingle maintained the smallest percentage of their healthy total leaf area $(12-17 \%)$.

Table 8. Leaf area $\left(\mathrm{cm}^{2}\right)$ per tree at 50 wai.

\begin{tabular}{|c|c|c|c|c|c|}
\hline \multirow{2}{*}{$\begin{array}{l}\text { Rootstock } \\
\text { US-812 }\end{array}$} & \multicolumn{2}{|c|}{$\begin{array}{l}\text { Leaf Area } \\
\text { per Tree } \\
\text { CLas neg }\end{array}$} & \multirow{2}{*}{$\begin{array}{c}\begin{array}{c}\text { Leaf Area } \\
\text { per Tree } \\
\text { CLas pos }\end{array} \\
1503\end{array}$} & \multicolumn{2}{|c|}{$\begin{array}{c}\text { Leaf Area } \\
\text { per Tree } \\
\text { pos/neg }(\%)\end{array}$} \\
\hline & 3494 & $a b$ & & 41 & $\mathrm{a}$ \\
\hline US-942 & 3803 & $\mathrm{ab}$ & 1485 & 37 & $\mathrm{a}$ \\
\hline US-802 & 3396 & $a b$ & 1216 & 35 & a \\
\hline Carrizo & 3528 & $\mathrm{ab}$ & 1151 & 31 & a \\
\hline US-1516 & 3160 & $\mathrm{ab}$ & 817 & 25 & a \\
\hline $\begin{array}{l}\text { Sour } \\
\text { orange }\end{array}$ & 4105 & $a b$ & 1015 & 25 & $\mathrm{a}$ \\
\hline US-896 & 3782 & $\mathrm{ab}$ & 790 & 21 & a \\
\hline US-897 & 2943 & $\mathrm{~b}$ & 563 & 19 & a \\
\hline Swingle & 3448 & $a b$ & 598 & 17 & $\mathrm{a}$ \\
\hline Ridge & 4478 & $\mathrm{a}$ & 868 & 17 & a \\
\hline Cleopatra & 4069 & $\mathrm{a}$ & 513 & 12 & a \\
\hline Average & 3655 & & 956 & 25 & \\
\hline$p$-value & 0.025 & & 0.237 & 0.036 & \\
\hline
\end{tabular}

Different letters within columns indicate significant differences according to Tukey's HSD test.

\subsection{Area per Leaf}

Mean area per leaf was reduced by CLas infection from $28.7 \mathrm{~cm}^{2}$ for healthy trees, to $19.4 \mathrm{~cm}^{2}$ for CLas-infected trees (Table 9), or a reduction of about $30 \%$. There was no significant effect of rootstock on the area per leaf for either healthy or CLas-infected trees. There was a significant rootstock effect on the ratio of area per leaf for healthy and CLas-infected trees $(p>\mathrm{F}=0.036)$, but no groups were identified in the Tukey post-hoc test.

Table 9. Area per leaf $\left(\mathrm{cm}^{2}\right)$ at 50 wai.

\begin{tabular}{lcccc}
\hline Rootstock & $\begin{array}{c}\text { Area } \\
\text { per Leaf } \\
\text { CLas neg }\end{array}$ & $\begin{array}{c}\text { Area } \\
\text { per Leaf } \\
\text { CLas pos }\end{array}$ & \multicolumn{2}{c}{$\begin{array}{c}\text { Area } \\
\text { per Leaf pos/neg (\%) }\end{array}$} \\
\hline Swingle & 24.7 & 20.5 & 89 & $\mathrm{a}$ \\
Carrizo & 24.1 & 19.6 & 82 & $\mathrm{a}$ \\
Ridge & 32.0 & 23.5 & 79 & $\mathrm{a}$ \\
Sour orange & 31.3 & 20.9 & 72 & $\mathrm{a}$ \\
US-1516 & 31.5 & 20.3 & 69 & $\mathrm{a}$ \\
US-896 & 26.5 & 18.0 & 69 & $\mathrm{a}$ \\
US-812 & 29.5 & 19.5 & 67 & $\mathrm{a}$ \\
US-802 & 30.0 & 19.2 & 64 & $\mathrm{a}$ \\
Cleopatra & 25.7 & 16.4 & 64 & $\mathrm{a}$ \\
US-942 & 33.6 & 19.1 & 61 & $\mathrm{a}$ \\
US-897 & 27.2 & 16.5 & 60 & $\mathrm{a}$ \\
Average & 28.7 & 19.4 & 70 & \\
p-value & 0.072 & 0.942 & 0.036 & \\
\hline
\end{tabular}

Different letters within columns indicate significant differences according to Tukey's HSD test. 


\section{Discussion}

The $\mathrm{Ct}_{\text {CLas }}$ values generally declined (indicating CLas bacterial titer increased) in Valencia sweet orange leaf tissue during the first 40 wai, and then nearly stabilized from $40-50$ wai at a value about equivalent to $0.8-1.2 \times 10^{6}$ CLas genomes per $g$ of leaf tissue. Unlike the scion leaves, the $\mathrm{Ct}_{\mathrm{CLas}}$ values for roots remained relatively high throughout the 50 wai, with averages not exceeding an equivalent of about 6000 CLas genomes per g root tissue. The reduced titer of CLas in leaves and roots of some P. trifoliata hybrids (as compared with Citrus clones) was reported in previous studies using the $\mathrm{Li}$ primers $[8,18]$. Some researchers have suggested that the Li primers used in our study fail to properly detect CLas in root tissues, and have developed alternative primers targeted at root assessment in field trees [25]. However, we believe that under carefully managed greenhouse conditions the Li primers can provide accurate relative assessments of CLas in the roots, and by using the same Li primers in leaf and root assessment, we can reasonably compare CLas titers in the two tissue types. Our results in this study make clear that the lower titer of CLas in root tissue than shoot tissue is true across a broad range of rootstock types, including some that are not hybrids of $P$. trifoliata. The increased HLB-tolerance of some rootstocks from P. trifoliata parentage has been demonstrated in the field $[15,16]$, and our results reported here confirm that observation. In this greenhouse study, some of the P. trifoliata rootstock hybrids that we tested as grafted trees, exhibited responses to CLas that may be interpreted as increased CLas-tolerance in the grafted trees. This increased HLB-tolerance of certain rootstocks may be associated with a reduced CLas titer in the roots, but the PCR results demonstrate that the influence of those rootstocks to increase HLB-tolerance of the grafted tree is not mediated by reduction of CLas titer in the scion itself.

One of the most often described symptoms of CLas infection in field trees, an asymmetrical blotchy mottle, was rarely observed in leaves of our CLas-positive trees. Based on previous reports of significant nutritional deficiencies associated with HLB disease, and the reduction of some HLB symptoms through improved nutritional management [5,6,26-29], we hypothesize that the optimal nutritional conditions for tree growth in our greenhouse may have masked some of the manifestations of CLas infection, such as blotchy mottle. It is unclear to what extent nutritional conditions might have similarly affected the expression of leaf yellowing.

Despite the lack of blotchy mottle symptoms, trees in the greenhouse experiment were clearly affected by CLas-infection, with the infection inducing a generalized yellowing of the leaves and causing a mean reduction of scion growth by $64 \%$, rootstock growth by $73 \%$, the number of leaves by $61 \%$, the total leaf area by $75 \%$, and area per leaf by $30 \%$. We hypothesize that the improved nutritional management in the greenhouse was able to correct only a small component of the negative effects from CLas infection that causes blotchy mottle, but did not correct other negative effects from the infection that have broader influence on tree health and growth. This may explain why some previous studies have presented conflicting information about the observed benefits from improved nutritional management for HLB disease [30].

Measurements of leaf color (yellowing), leaf number, and total leaf area at 50 wai provided evidence for rootstock influence on health of the grafted Valencia sweet orange trees. All three parameters provided a similar indication that CLas was less damaging to Valencia trees grafted on the rootstocks US-942 and US-812 (both hybrids of C. reticulata 'Sunki' $\times$ P. trifoliata), and more damaging to Valencia trees grafted on the rootstocks Ridge, Swingle, and perhaps Cleopatra. This corresponds well with field observations on these and other similar rootstocks in field trials strongly affected by CLas infection $[15,16]$. It can be noted that another study has evaluated the incidence of CLas-infection among Sunki $\times$ P. trifoliata hybrids under field conditions [31]. The observed association of rootstock with the scion leaf yellowing, leaf number, and total leaf area in our greenhouse study presents the strongest case for the assay as a predictor of rootstock field tolerance, since these three vegetative traits are what might most often be associated with observed tolerance in field trees (at least in the absence of fruit). 
Rootstock had a large influence on scion growth in trees not infected by CLas, with Ridge rootstock creating the largest and fastest growing trees and Swingle rootstock creating the smallest and slowest growing. There was, however, no evidence that rootstock significantly affected the growth of CLas-infected trees during the timeframe of the study. It seems likely this failure to identify relative growth affects from rootstocks in CLas-infected trees is a result of the relatively short duration over which growth was measured, in combination with the restricted growth imposed by the nursery container. We anticipate that the significant impact of the different rootstocks on the canopy area and leaf yellowing of trees at 50 wai should result in different rates of growth in longer duration studies, and where container size is not limiting. The assay conditions of future studies may be modified to use larger pots and longer duration to allow the observation of potential effects of tolerance on tree growth.

The results from this study provide good support for the observations from field trials indicating differential influence of rootstocks on CLas-tolerance of trees grafted with sensitive scions like sweet orange. It is unclear whether this improved field-tolerance of trees on certain rootstocks is the result of: (1) The increased CLas-tolerance of the rootstock itself, without direct influence on the tolerance of the scion, (2) the rootstock influence to increase CLas-tolerance of the scion, or (3) an increased generalized health of the rootstock that is not specifically associated with CLas infection. Previous studies provide some clues as to the basis for HLB disease symptom development [32-35], causes for the observed CLas tolerance of some hybrid rootstocks $[19,36]$, the ways in which the rootstock affects the metabolism of the scion [37], and the possible modes by which the rootstock can increase HLB-tolerance of the grafted tree [20]. The results from this study provide a tool to accelerate evaluation of new rootstocks and other HLB-mitigation strategies during the preliminary stage of evaluation, by replacing long-term field trials with 50-week greenhouse testing. Further study of the growth, physiological, and metabolic effects of different genotypes on the response to CLas infection will expand our ability to create HLB-tolerant rootstocks and scions, as well as other methods for managing this disease.

Author Contributions: Conceptualization, methodology, software, validation, formal analysis, investigation, resources, writing - original draft preparation, writing - review and editing, K.D.B. and U.A.; data curation, visualization, supervision, project administration, funding acquisition, K.D.B. All authors have read and agreed to the published version of the manuscript.

Funding: This research was funded by the Citrus Research and Development Foundation.

Acknowledgments: We would like to thank Diane Helseth, Sailindra Patel, Kerry Worton, and Emily Domagtoy for their help with tree manipulations, data collection, and sample collection and analysis.

Conflicts of Interest: The authors declare no conflict of interest. The funders had no role in the design of the study; in the collection, analyses, or interpretation of data; in the writing of the manuscript, or in the decision to publish the results.

\section{References}

1. Morris, A. What is happening to the orange juice market? Citrus Ind. 2017. Available online: https://citrusindustry.net/2017/09/11/what-is-happening-to-the-orange-juice-market/ (accessed on 11 September 2017).

2. Industry News Release. Florida citrus acres declining. Citrus Ind. 2020. Available online: https:// citrusindustry.net/2020/08/31/florida-citrus-acres-declining/ (accessed on 1 October 2020).

3. Qureshi, J.A.; Kostyk, B.C.; Stansly, P.A. Insecticidal Suppression of Asian Citrus Psyllid Diaphorina citri (Hemiptera: Liviidae) Vector of Huanglongbing Pathogens. PLoS ONE 2014, 9, e112331. [CrossRef] [PubMed]

4. Diepenbrock, L.M.; Qureshi, J.; Stelinski, L. 2020-2021 Florida Citrus Production Guide: Asian Citrus Psyllid; IFAS publication CG097; University of Florida Institute of Food and Agricultural Sciences: Gainesville, FL, USA, 2020; Available online: http://edis.ifas.ufl.edu/pdffiles/CG/CG09700.pdf (accessed on 1 October 2020).

5. Morgan, K.T.; Rouse, R.E.; Ebel, R.C. Foliar Applications of Essential Nutrients on Growth and Yield of 'Valencia' Sweet Orange Infected with Huanglongbing. HortScience 2016, 51, 1482-1493. [CrossRef]

6. Rouse, R.E.; Ozores-Hampton, M.; Roka, F.M.; Roberts, P. Rehabilitation of huanglongbing-affected citrus trees using severe pruning and enhanced foliar nutritional treatments. HortScience 2017, 52, 972-978. [CrossRef] 
7. Killiny, N.; Jones, S.E.; Nehela, Y.; Hijaz, F.; Dutt, M.; Gmitter, F.G.; Grosser, J.W. All roads lead to Rome: Towards understanding different avenues of tolerance to huanglongbing in citrus cultivars. Plant Physiol. Biochem. 2018, 129, 1-10. [CrossRef] [PubMed]

8. Albrecht, U.; Bowman, K.D. Reciprocal influence of rootstock and scion citrus cultivars challenged with Ca. Liberibacter asiaticus. Sci. Hortic. 2019, 254, 133-144. [CrossRef]

9. Castle, W.S.; Bowman, K.D.; Grosser, J.W.; Ferrarezi, R.S.; Futch, S.H.; Rogers, S. Florida Citrus Rootstock Selection Guide, 4th ed.; IFAS Publication SP248; University of Florida Institute of Food and Agricultural Sciences: Gainesville, FL, USA, 2019; Available online: https://edis.ifas.ufl.edu/pdffiles/HS/HS126000.pdf (accessed on 1 October 2020).

10. Wutscher, H.K. Citrus rootstocks. Hort. Rev. 1979, 1, 237-269.

11. Castle, W.S. A career perspective on citrus rootstocks, their development, and commercialization. HortScience 2010, 45, 11-15. [CrossRef]

12. Bowman, K.D.; Joubert, J. Citrus rootstocks. In The Genus Citrus; Talon, M., Caruso, M., Gmitter, F.G., Eds.; Woodhead Publishing: Cambridge, UK, 2020; pp. 105-127.

13. Albrecht, U.; Bowman, K.D. Tolerance of the trifoliate citrus hybrid US-897 (Citrus reticulata $\times$ Poncirus trifoliata) to huanglongbing. HortScience 2011, 46, 16-22. [CrossRef]

14. Albrecht, U.; Bowman, K.D. Tolerance of trifoliate citrus rootstock hybrids to Candidatus Liberibacter asiaticus. Sci. Hortic. 2012, 147, 71-80. [CrossRef]

15. Bowman, K.D.; Faulkner, L.; Kesinger, M. New citrus rootstocks released by USDA 2001-2010: Field performance and nursery characteristics. HortScience 2016, 51, 1208-1214. [CrossRef]

16. Bowman, K.D.; McCollum, G.; Albrecht, U. Performance of 'Valencia' orange (Citrus sinensis [L.] Osbeck) on 17 rootstocks in a trial severely affected by huanglongbing. Sci. Hortic. 2016, 201, 355-361. [CrossRef]

17. Albrecht, U.; Bowman, K.D. Transcriptional response of susceptible and tolerant citrus to infection with Candidatus Liberibacter asiaticus. Plant Sci. 2012, 185-186, 118-130. [CrossRef]

18. Bowman, K.D.; Albrecht, U. Comparison of gene expression changes in susceptible, tolerant, and resistant hosts in response to infection with Citrus tristeza virus and huanglongbing. J. Citrus Pathol. 2015, 2, 1-6.

19. Albrecht, U.; Fiehn, O.; Bowman, K.D. Metabolic variations in different citrus rootstock cultivars associated with different responses to Huanglongbing. Plant Physiol. Biochem. 2016, 107, 33-44. [CrossRef]

20. Albrecht, U.; Tripathi, I.; Bowman, K.D. Rootstock influences the metabolic response to Candidatus Liberibacter asiaticus in grafted sweet orange trees. Trees 2020, 34, 405-431. [CrossRef]

21. Bisi, R.B.; Albrecht, U.; Bowman, K.D. Seed and seedling nursery characteristics for 10 USDA citrus rootstocks. HortScience 2020, 55, 528-532. [CrossRef]

22. Bowman, K.D. Comparison of two citrus bud-forcing methods for rapid propagation of scions on new hybrid citrumelo rootstocks. HortScience 1999, 34, 142-143. [CrossRef]

23. Li, W.; Hartung, J.S.; Levy, L. Quantitative real-time PCR for detection and identification of Candidatus Liberibacter species associated with citrus huanglongbing. J. Microbiol. Methods 2006, 66, 104-115. [CrossRef]

24. Burrow, J.D.; Dewdney, M.M. Huanglongbing (HLB; Citrus Greening) Leaf and Fruit Symptom Identification; IFAS Publication PP327; University of Florida Institute of Food and Agricultural Sciences: Gainesville, FL, USA, 2019.

25. Park, J.-W.; Louzada, E.S.; Braswell, W.E.; Stansly, P.A.; da Graca, J.V.; McCollum, G.; Rascoe, J.E.; Kunta, M. A new diagnostic real-time PCR method for huanglongbing detection in citrus root tissue. J. Gen. Plant Pathol. 2018, 84, 359-367. [CrossRef]

26. Inoue, H.; Yamashita-Muraki, S.; Fujiwara, K.; Honda, K.; Ono, H.; Nonaka, T.; Kato, Y.; Matsuyama, T.; Sugano, S.; Suzuki, M.; et al. $\mathrm{Fe}^{2+}$ ions alleviate the symptom of citrus greening disease. Int. J. Mol. Sci. 2020, 21, 4033. [CrossRef]

27. Masaoka, Y.; Pustika, A.; Subandiyah, S.; Okada, A.; Hanundin, E.; Purwanto, B.; Okuda, M.; Okada, M.; Saito, A.; Holford, P. Lower Concentrations of Microelements in Leaves of Citrus Infected with “Candidatus Liberibacter asiaticus". Jpn. Agric. Res. Q. 2011, 45, 269-275. [CrossRef]

28. Pustika, A.B.; Subandiyah, S.; Holford, P.; Beattie, G.A.C.; Iwanami, T.; Masaoka, Y. Interactions between plant nutrition and symptom expression in mandarin trees infected with the disease Huanglongbing. Australas. Plant Dis. Notes 2008, 3, 112-115. [CrossRef] 
29. Zhao, H.; Sun, R.; Albrecht, U.; Padmanabhan, C.; Wang, A.; Coffey, M.D.; Girke, T.; Wang, Z.; Close, T.J.; Roose, M.; et al. Small RNA profiling reveals phosphorus deficiency as one of the major factors for the pathogenesis of citrus Huanglongbing (HLB) disease. Mol. Plant 2013, 6, 301-310. [CrossRef]

30. Gottwald, T.R.; Graham, J.H.; Irey, M.S.; McCollum, T.G.; Wood, B.W. Inconsequential effect of nutritional treatments on huanglongbing control, fruit quality, bacterial titer and disease progress. Crop Prot. 2012, 36, 73-82. [CrossRef]

31. Boava, L.P.; Sagawa, C.H.D.; Cristofani-Yaly, M.; Machado, M.A. Incidence of 'Candidatus Liberibacter asiaticus'-Infected plants among citrandarins as rootstock and scion under field conditions. Phytopathology 2015, 105, 518-524. [CrossRef] [PubMed]

32. Folimonova, S.Y.; Robertson, C.J.; Garnsey, S.M.; Gowda, S.; Dawson, W.O. Examination of the responses of different genotypes of citrus to Huanglongbing (citrus greening) under different conditions. Phytopathology 2009, 99, 1346-1354. [CrossRef] [PubMed]

33. Nwugo, C.C.; Lin, H.; Duan, Y.; Civerolo, E.L. The effect of 'Candidatus Liberibacter asiaticus' infection on the proteomic profiles and nutritional status of pre-symptomatic and symptomatic grapefruit (Citrus paradisi) plants. BMC Plant Biol. 2013, 13, 59. [CrossRef]

34. Johnson, E.G.; Wu, J.; Bright, D.B.; Graham, J.H. Association of 'Candidatus Liberibacter asiaticus' root infection, but not phloem plugging with root loss on huanglongbing-affected trees prior to appearance of foliar symptoms. Plant Pathol. 2014, 63, 290-298. [CrossRef]

35. Zhong, Y.; Cheng, C.-Z.; Jiang, N.-H.; Jiang, B.; Zhang, Y.-Y.; Wu, B. Comparative Transcriptome and iTRAQ Proteome Analyses of Citrus Root Responses to Candidatus Liberibacter asiaticus Infection. PLoS ONE 2015, 10, e0126973. [CrossRef]

36. Wu, J.; Alferez, F.M.; Johnson, E.G.; Graham, J.H. Up-regulation of PR1 and less disruption of hormone and sucrose metabolism in roots is associated with lower susceptibility to 'Candidatus Liberibacter asiaticus'. Plant Pathol. 2018, 67, 1426-1435. [CrossRef]

37. Albrecht, U.; Tripathi, I.; Kim, H.Y.; Bowman, K.D. Rootstock effects on metabolite composition in leaves and roots of young navel orange (Citrus sinensis L. Osbeck) and pummelo (C. grandis L. Osbeck) trees. Trees 2018, 33, 243-265. [CrossRef]

Publisher's Note: MDPI stays neutral with regard to jurisdictional claims in published maps and institutional affiliations.

(C) 2020 by the authors. Licensee MDPI, Basel, Switzerland. This article is an open access article distributed under the terms and conditions of the Creative Commons Attribution (CC BY) license (http://creativecommons.org/licenses/by/4.0/). 